Article

\title{
Qualitative Exploration of Perception and Use of Cultural Ecosystem Services from Tree-Based Urban Green Space in the City of Zagreb (Croatia)
}

\author{
Silvija Krajter Ostoić *, Ana Marija Marin, Martina Kičić and Dijana Vuletić ${ }^{\circledR}$ \\ Department for International Scientific Cooperation in Southeast Europe-EFISEE, Croatian Forest Research \\ Institute, Cvjetno naselje 41, 10450 Jastrebarsko, Croatia; anamari@sumins.hr (A.M.M.); \\ martinak@sumins.hr (M.K.); dijanav@sumins.hr (D.V.) \\ * Correspondence: silvijak@sumins.hr
}

Received: 30 June 2020; Accepted: 6 August 2020; Published: 11 August 2020

check for updates

\begin{abstract}
Background and Objectives: Cultural ecosystem services of urban green spaces are increasingly important and often recognized as such by people living in urban areas. Qualitative studies on perception of cultural ecosystem services from urban green spaces are still rare. Previous studies addressed only certain types of urban green space and often only some services. There is a lack of understanding how people perceive cultural ecosystem services from different types of tree-based urban green spaces. Hence, the purpose of the study was to explore whether and how people perceive and use cultural ecosystem services of different types of tree-based urban green spaces. Materials and Methods: Focus groups were conducted with citizens in each city district. Interviews were recorded, transcribed and transcripts analyzed in MAXQDA software. We used bottom up code-category-theme approach to analyze the data without predefined set of codes or categories. Results: Place attachment, aesthetic and recreational services were more recognized than educational and cultural identity services. For place attachment, most important single attributes were positive memories, and good maintenance, while most important categories were facilities, existence of emotional ties, possibility of experiences, recreational use and access. Presence of specific tree species and presence of trees in general were most important attributes for aesthetic services, while possibility of experiences and trees were the most important categories. Conclusions: People perceived various cultural ecosystem services from tree-based urban green space, even though some services more than others. Recreation may be the underlying goal of our participants when interacting with tree-based urban nature. Forests, parks were recognized as those providing multiple cultural ecosystem services. However, other types of green spaces were also recognized as bearers of these services, albeit with less services and attributes attached. It supports the importance of careful planning of urban green spaces in terms of providing a variety of green space types. The study provides basis for later quantification of cultural ecosystem services (CES) from tree-based urban green space.
\end{abstract}

Keywords: perception; cultural ecosystem services; place attachment; aesthetics; recreation; education; cultural identity; focus groups; qualitative approach; Zagreb; Croatia

\section{Introduction}

Cultural ecosystem services (CES) are becoming increasingly important due to prevalence of people living in urban areas [1,2] and due to prevalence of cultural landscapes, especially in Europe [3]. Millennium Ecosystem Assessment defines CES as "nonmaterial benefits people obtain from ecosystems through spiritual enrichment, cognitive development, reflection, recreation, and esthetic 
experiences" [4]. In comparison to other groups of ecosystem services these are less explored due to their often intangible character [5]. Even different types of CES are unevenly explored. For instance, recreation, ecotourism and aesthetic values are among those most explored [5]. The same review paper found other CES, such as spiritual, educational or cultural heritage values are much less present in the scientific discourse.

Urban green space (UGS), in particular those tree-based, provides many ecosystem services to urban residents and hence contributes to their wellbeing [6-8]. Among groups of ecosystem services, CES are usually those highly appreciated $[9,10]$. UGS, in particular urban woodlands/forests are considered as cultural landscapes, those that are produced in the interaction with urban residents [11].

In its definition of landscape, the European Landscape Convention, puts an emphasis on people's perception, and defines it as an "area as perceived by people" [12]. Indeed, human perceptions and preferences with regard to natural resources, or more generally human-nature interaction, have been in a focus of environmental psychology for some time [13]. In the meantime, several theories trying to explain human landscape perception and preferences have been developed based on their claim that preferences are either innate or learned. On one side there are evolutionary theories claiming that preferences are result of evolution and hence innate. On the other side are cultural theories claiming that preferences are learned, due to being shaped by social, cultural and personal characteristics [14]. Research shows some landscape preferences are universal regardless of people's cultural background, such as positive response to presence of water bodies [15], while some might differ across cultures, such as preference for openness [16], or perception of crowding [17]. Some studies focus on perception of specific elements of UGS design, for instance openness [16] or naturalness [18]. Other address certain traits of trees, such as preference for colors, size, age, broadleaves or conifers, crown tree elements [19-22].

A recent review [23] suggests that to successfully identify CES in UGS a variety of methods, including both qualitative and quantitative as well as inductive approaches, should be applied. This same work highlights a scarcity of studies qualitatively addressing CES (but see [24]) and often the investigated UGS type is not specified. Furthermore, these studies frequently include parks [10,25-28] and forests [29], rather than other types of UGS (but see [30-32]). However, there is a need to explore how CES are related to different types of UGS [29]. It would help in understanding how people perceive different types of UGS with regard to their ability to provide various CES.

The main aims of the paper are to present results of the city-wide qualitative exploratory analysis of (a) whether and how people perceive CES of tree-based UGS, and (b) whether and how perception and use differs based on the type of tree-based UGS. The study addressed place attachment, aesthetics, recreation, educational and cultural identity services. We assumed that people would perceive some CES better than others and that CES they attach to tree-based UGS would differ based on the type of UGS in a sense that some types of UGS will be perceived as providing more and different services than the other.

\section{Materials and Methods}

\subsection{Study Area}

The city of Zagreb, the Croatian capital and largest city was taken as a case study. The reason for this is existence of previous studies eliciting public perceptions, attitudes and use of public UGS, as well as governance aspects [33-35]. Researchers involved are all familiar with the context both as residents and through their previous research related to this city's UGS. Zagreb comprises 17 city districts and 218 community boards representing local self-government that is coordinated by the City Office for Local Self-Administration [36]. The city of Zagreb is also one of the 21 regional territorial units (counties) of the Republic of Croatia, hence it acts both as city and the county. General information on the city and its urban green space is provided in the Table 1. 
Table 1. General information on the city of Zagreb and its urban green space. Source: Statistical Yearbook of the City of Zagreb for 2019 [36].

\begin{tabular}{ccc}
\hline City of Zagreb & & \\
\hline Geographical location & Longitude & $15^{\circ} 59^{\prime}$ East \\
Surface area & Latitude & $45^{\circ} 49^{\prime}$ North \\
Population in 2018 (estimate) & & $641.32 \mathrm{~km}^{2}$ \\
Population by gender (2018, mid-year estimate) & Number & 804,507 \\
Population by age (2018, mid-year estimate) & Male & $47 \%$ \\
& Female & $53 \%$ \\
& $15-29$ & $16 \%$ \\
Urban green space & $30-44$ & $23 \%$ \\
& $45-59$ & $20 \%$ \\
& Par & $26 \%$ \\
& Porests (state-owned) & $59.2 \mathrm{ha}$ \\
& Forests (privately-owned) & $9838 \mathrm{ha}$ \\
& Grassland & $159 \mathrm{ha}$ \\
& Botanical gardens & $7.1 \mathrm{ha}$ \\
& Zoological garden & $7 \mathrm{ha}$ \\
& Tree-lined roads & $243 \mathrm{~km}$ \\
& Public playgrounds & $\mathrm{N}=760$ \\
& Dog parks & $\mathrm{N}=10$ \\
& Protected natural areas & $9492.28 \mathrm{ha}$ \\
\hline
\end{tabular}

According to types of land use about the same proportion is allocated to forest area, agricultural land and built area [36]. According to Krajter Ostoić [35], UGS, such as parks, tree lines or neighborhood green, is responsibility of the city owned company, while forests and park forests are the responsibility of the state owned forest management company. Maintenance of park forests is coordinated by the city administration which provides funding for the forest management company. Public green space management, maintenance or establishment of new UGS is completely funded from the city budget. The information on UGS other than forests provided in the Table 1 refers only to UGS that are the responsibility of the city administration (in terms of urban and green space planning, as well as funding) and the city company (in terms of maintenance and establishment of new UGS). Information on protected natural areas includes all protected areas regardless of the category of protection. Since it is impossible to describe all UGSs in the city of Zagreb, we will further mention only some that are widely recognized by its residents and beyond. The biggest protected area is Nature Park Medvednica, a forested area on the mountain of the same name, which accounts for approx. 8500 ha within the city boarders. One of the iconic UGSs in the city of Zagreb is historical park Maksimir, the first public park in the Southeast Europe (established in 1794), and one of the first of the kind in general, purposely visited by many even those living outside Zagreb [37]. The other iconic UGS, Gesamtkunstwerk Green Horseshoe, is actually an urbanistically planned network of green spaces (seven square parks and a botanical garden) located in the city center, whose development started in the second half of the 19th century [38]. From other UGS specifically important is the sports and recreation area Jarun, hosting the artificial lake of the same name, and providing many cultural, sports and recreational opportunities. The area was developed in the 1980s as a stage for the XIV Universiade (university summer Olympics event) that took place in Zagreb in 1987. Park-forests close to the city center are located in somewhat elite residential areas and connect city center with the forests on the mountain Medvednica [39]. River Sava that runs through Zagreb and splits it into the Old and New Zagreb, has historical and cultural significance for Zagreb residents [40]. A greenway located on the both banks along the river Sava is nowadays an important recreational area. 


\subsection{Focus Group Method and Data Analysis}

The goal of the research was to explore how people perceive and use CES from tree-based UGSs, as well as whether and how perception and use differs with regard to type of UGS. Here we are presenting results of the first phase of a larger project addressing participatory mapping of CES and disservices from UGSs. Due to lack of previous similar research in the study area, employing a qualitative approach, specifically focus group methodology, was a reasonable choice. Focus group is a qualitative method, a group interview, particularly useful for deeper understanding of human perceptions, attitudes, motivations or behavior [41,42]. It has been applied in various disciplines [42,43]. The method is often used in combination with quantitative methods (survey) providing explanations for findings of quantitative studies, or when conducted prior to survey, to fine tune the survey instrument. The latter is true for our study. Results of the focus groups in combination with literature review would serve as an input for the public participatory Geographic Information System (GIS) survey questionnaire in the second phase of the project. Focus groups can elicit a wide variety of responses in relatively short time, and researcher can get a grasp of how people talk about the phenomenon of interest [41]. In comparison to quantitative methods, such as surveys, results of focus groups do not allow generalization due to small number of participants [41,42]. However, there is no consensus on the ideal number of participants. Rule of the thumb says that it should be small enough to allow each participant to express his/her opinion, but large enough to allow group dynamics during the interview [42].

Focus group protocol with questions addressing several CES was developed as a guide for moderators (Appendix A). The protocol included introductory part about the project and its goals, the need to record the session, how data will be analyzed and reported as well as information about rights of the participants. The questions were related to their dearest UGS, those they use for recreational purposes, those they consider beautiful, those important for the district's or city's cultural identity and UGS they avoid for some reasons. The questions were posed in a way to encourage discussion and avoid yes or no answers. Participants were encouraged not only to name UGSs but also to explain their choices (e.g., why a person considers a certain UGS beautiful). In the end of the focus groups each participant filled in a short sociodemographic questionnaire (Appendix B). In addition to general sociodemographic information on their gender, age and achieved level of education we asked them about whether they live in a house or an apartment building, whether they grew up in the city or at the countryside, for how long they have been living in Zagreb and in their particular city district, size of the household, employment status, number of children in the household and monthly income or their household.

The study was approved by the Ethics Committee of Croatian Forest Research Institute. We conducted 20 focus groups covering all city districts (at least one per city district). Informed consent was achieved at the beginning of each focus group. Majority of focus groups (14) took place between 21 March and 2 June 2019 in the facilities of the local self-government of the City of Zagreb. The rest were conducted in the public libraries of the Zagreb City Libraries (6) between 15 October and 11 November 2019. Participants were recruited through invitations posted on frequently used public places, though e-mails sent to elected representatives at different local self-government levels, as well as through personal contacts. Both elected representative and personal contacts were kindly asked to participate themselves and/or to pass the information to their contacts. We were also invited to several interviews at the local radio and TV channels. Participants were not offered any incentives beside warm drinks (tea or coffee) at the site. Size of groups varied and on average included five participants.

Focus groups were moderated by the principal investigator and two $\mathrm{PhD}$ students as team members. In each focus group a team member acted as moderator, and another two team members as assistants. One assistant acted as note taker and the other helped participants in finding certain locations on the map they were talking about. Team members took turns in each role. Focus group participants had a colored map of their neighborhood at their disposal and an assistant's role was to place colored self-adhesive dots on places on the map the focus groups participant was referring 
to when answering questions, different color for each question. Focus groups were conducted in local language (Croatian), audio-recorded and transcribed verbatim. We translated into English only excerpts reported in this paper.

Transcripts were coded in MAXQDA 10 software by the principal investigator. However, all results and conclusions were discussed within the team along the way, the process as such being in line with Harry and others [44]. Coding was done according to code-category-theme analytical approach for qualitative data analysis [45]. We analyzed textual data so codes in our case referred to portions of data that ranged from a word to a short phrase. Similar codes were further grouped or organized into categories, and groups of categories were assigned to major themes. In our study those themes referred to certain ecosystem services we explored, namely place attachment, aesthetics, recreation, education and cultural identity. Two additional themes we covered were disservices and suggestions on improvement, but there results are not reported here. In order to describe how codes were connected to categories and theme we will take the place attachment theme as an example. Within the theme of place attachment, we were able to identify several categories (e.g., 'emotional ties', 'accessibility', 'maintenance', etc.). To the category emotional ties we attributed several codes (e.g., 'childhood spent', 'resemblance to birth place, "I feel emotional connection", etc.). The coding process was bottom up in a way that it was not led by predefined set of codes and categories. However, a literature review conducted prior to the focus groups certainly informed our decisions during the process of coding in terms of naming the codes or organizing the codes into categories. We identified codes by combining several coding methods described in Saldaña [45]. The process of coding started with initial or open coding during which researcher coded everything considered useful for further analysis, by splitting the data into small codable units, and these initial codes were refined later through several coding iterations. Whenever possible and useful for further analysis we applied in-vivo coding, which means coding words or phrases by using exact words of participants. Examples of such codes are "I feel emotional connection" or "I feel as I am in paradise". Sometimes same passages of text were coded several times, what is known as simultaneous coding. For instance when a participant refers in the same portion of text to his/her dearest place (theme of place attachment), considers it beautiful (theme of aesthetics) at the same time explaining how he/she uses the area for recreational purposes (theme of recreation).

Since our second goal was to explore which ecosystem services from UGS people associate with certain types of UGSs, we also connected our codes, categories and themes to those types. The UGS typology was created by researchers. Sometimes participants were aware of the types of UGS, usually for forests and parks, but were not aware of professional terminology, such as green system or greenway, or at least they did not use it. Sometimes they only described location (e.g., UGS close to the supermarket in the street $\mathrm{x}$ ), because they did not know the name of the UGS or it does not have a name.

We were interested in grasping the diversity of codes and categories associated with each ecosystem service, and not in quantifying their occurrence. So in the results we will not report the frequency of codes, but merely connections between the code or ecosystem service (theme) and the type of UGS. The quantification will be in focus of the second stage of the project through applying public participatory GIS survey questionnaire.

\subsection{Description of the Sample}

Our sample was purposive and hence does not allow generalization, but this was not the goal of the study in the first place. Instead of being able to generalize, our goal was to collect diversity of responses from our focus group participants in order to help in developing and calibrating survey instrument that will be used later on the larger sample of Zagreb residents. Altogether, 94 adults participated (Table 2). The only criterion for participants was that they live in the city district in which the focus group took place. We assumed that, in general, people would be more knowledgeable about green space in their city district. The other reason is that we wanted to tap into the specifics of each 
district and possibly unearth information on locally important tree-based UGSs that may not be evident to people living outside those city districts. On average our participants had been living in Zagreb for 43 years, and in their city district for 33 years.

Table 2. Sociodemographic information on focus group participants $(n=94)$.

\begin{tabular}{ccc}
\hline Variable & Category & Percentage of Respondents (\%) \\
\hline Gender & Male & $43 \%$ \\
& Female & $57 \%$ \\
\hline \multirow{2}{*}{ Age } & $15-29$ & $4 \%$ \\
& $30-44$ & $22 \%$ \\
& $45-59$ & $34 \%$ \\
& $\geq 60$ & $40 \%$ \\
\hline \multirow{2}{*}{ Education } & Elementary & $3 \%$ \\
& Secondary & $31 \%$ \\
& Higher & $66 \%$ \\
\hline \multirow{2}{*}{ Work Status } & Employed & $55 \%$ \\
& Unemployed & $11 \%$ \\
& Retired & $34 \%$ \\
\hline
\end{tabular}

We did not ask them about their motivations to participate in the study, but sometimes prior or after the focus groups some of them said that they came to the focus group to express their concern with some observed practices related to UGSs they considered negative, such as perceived lack of maintenance or excessive tree felling, or to give ideas on how to improve existing UGSs.

The sociodemographic profile of our respondents on average shows that the share of males and females in the sample was close to balance when compared to census data (Tables 1 and 2). Age distribution covered well working population and retirees. Share of respondents with higher education was higher than in general population.

\section{Results}

\subsection{Place Attachment}

Focus group participants used a variety of attributes to describe their dearest place(s) (Table 3). These attributes were grouped into the following categories: accessibility (when they talked about their favorite tree-based UGS in the context of availability of such space), maintenance (when they referred to the quality of management/maintenance of UGSs), experiences (when they talked about how particular places are exciting, wild, etc.), presence of other people (when discussed in the context of being crowded or visited by less or no people), beauty (when they explicitly said that something in the place is beautiful), presence of water bodies (when mentioning lakes, rivers, streams, etc.), emotional ties (when they mentioned specific emotions and connectedness to the place, for instance childhood or other previous memories connected to the place), recreational use (when they talk about how they use their favorite place or about its recreational potential), spiritual and restorative (when they discussed how the place makes them feel relaxed or puts them in a meditative state), facilities (when they talked about certain facilities available), presence of historical and architectural objects (e.g., churches, ruins, bridges), 'trees' (when they discuss different features of trees, e.g., type, size, age, color), naturalness, openness, shade (presence of shade from trees), role in air quality (when discussing their dearest place in the context of oxygen supply and air purification), place perceived as valuable (when some place is perceived as valuable per se or due to scarcity of public green space in the neighborhood or city district), attributes non-related to UGSs (for instance absence of traffic). Attributes were attached as well to the different types of tree-based UGSs (Table 3). 
Table 3. Categories and attributes with regard to favorite/dearest tree-based urban green space (UGS). Green indicates the assignation of an attribute to particular type of UGS (F—forest, P—park, WP—walking paths along the streams, TL—-tree lines, PF—park forest, GB — greenery around residential buildings, CP—children playgrounds, SR - greenery of sports and recreational facilities, T—-trees, PG—private garden, WV—window view, C—cemeteries, GS—green system, GW—greenway, $\mathrm{O}-$ other). Quotations refer to verbatim statements of the participants.

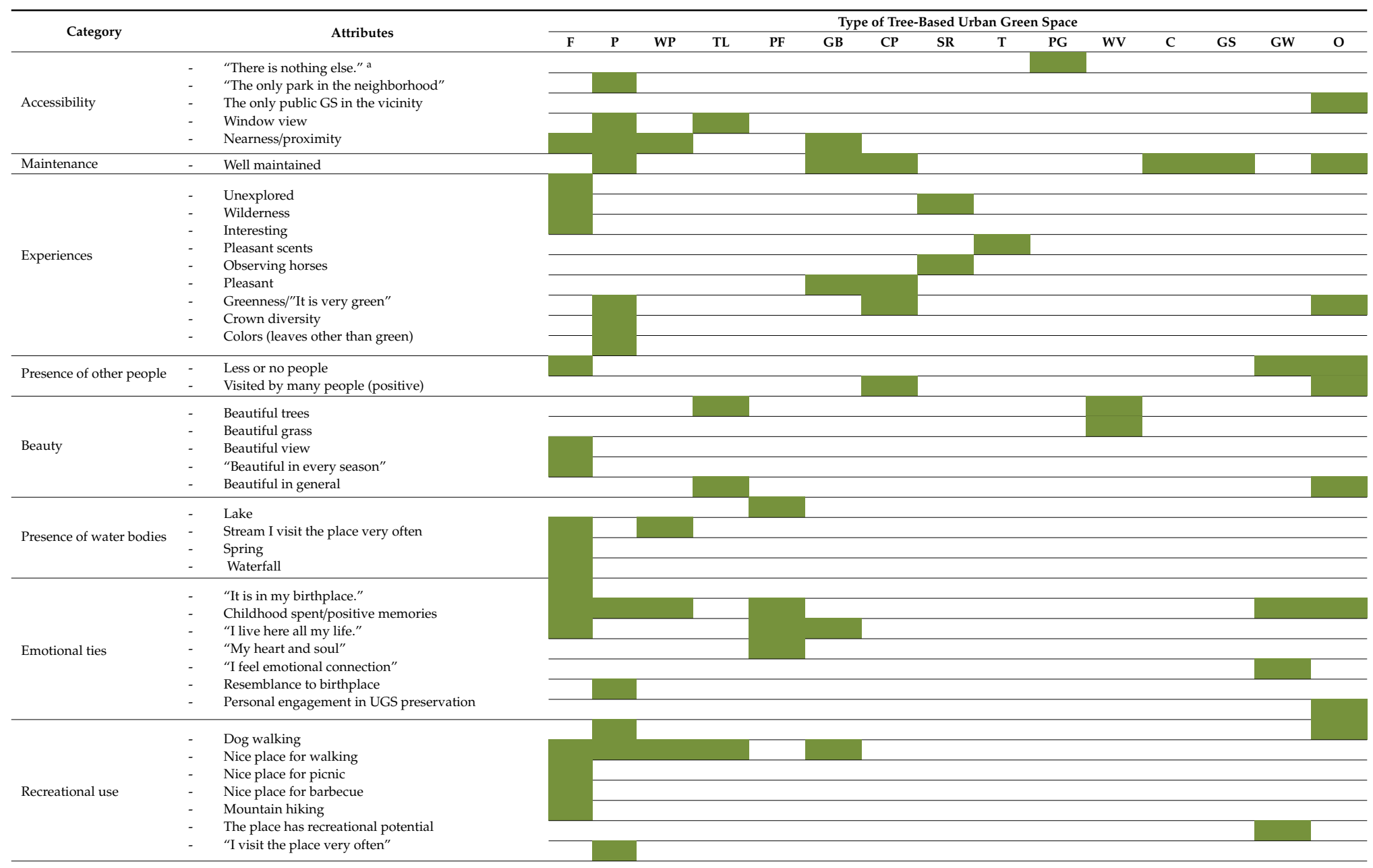


Table 3. Cont.

\begin{tabular}{|c|c|c|c|c|c|c|c|c|c|c|c|c|c|c|c|c|}
\hline \multirow{2}{*}{ Category } & \multirow{2}{*}{ Attributes } & \multicolumn{15}{|c|}{ Type of Tree-Based Urban Green Space } \\
\hline & & F & $\mathbf{P}$ & WP & TL & PF & GB & $\mathrm{CP}$ & SR & $\mathrm{T}$ & PG & WV & $\mathrm{C}$ & GS & GW & $\mathrm{O}$ \\
\hline \multirow{3}{*}{ Spiritual and restorative } & - $\quad$ Peace and quiet & & & & & & & & & & & & & & & \\
\hline & - "It is green everywhere." & & & & & & & & & & & & & & & \\
\hline & $\begin{array}{ll}\text { - } & \text { Rests the eyes } \\
\text { "Little green oasis" }\end{array}$ & & & & & & & & & & & & & & & \\
\hline \multirow{4}{*}{ Facilities } & - Presence of facilities & & & & & & & & & & & & & & & \\
\hline & $\begin{array}{ll}\text { - } & \text { Presence of children playgrounds } \\
\text { Suitable for kids }\end{array}$ & & & & & & & & & & & & & & & \\
\hline & - Suitable for all types of users/visitors & & & & & & & & & & & & & & & \\
\hline & $\begin{array}{ll}\text { Walking paths } \\
\text { Paths long enough for runners }\end{array}$ & & & & & & & & & & & & & & & \\
\hline \multirow{5}{*}{ Naturalness } & - $\quad$ True forest & & & & & & & & & & & & & & & \\
\hline & - Preserved nature & & & & & & & & & & & & & & & \\
\hline & - Presence of animals (birds of prey) & & & & & & & & & & & & & & & \\
\hline & - Wild & & & & & & & & & & & & & & & \\
\hline & - $\quad$ Presence of forest & & & & & & & & & & & & & & & \\
\hline Shade & - $\quad$ Presence of shade (from trees) & & & & & & & & & & & & & & & \\
\hline \multirow{3}{*}{ Openness } & - No other objects (to block the view) & & & & & & & & & & & & & & & \\
\hline & $\begin{array}{l}\text { - "I can breathe freely" } \\
\text { - Sense of freedom }\end{array}$ & & & & & & & & & & & & & & & \\
\hline & - $\quad$ Big open space & & & & & & & & & & & & & & & \\
\hline \multirow{2}{*}{$\begin{array}{l}\text { Presence of historical } \\
\text { and architectural objects }\end{array}$} & - $\quad$ Refurbished old water mills & & & & & & & & & & & & & & & \\
\hline & $\begin{array}{ll}- & \text { Stone pathways } \\
\text { - } & \text { (Wooden) bridges }\end{array}$ & & & & & & & & & & & & & & & \\
\hline \multirow{4}{*}{ Trees } & - $\quad$ Old trees & & & & & & & & & & & & & & & \\
\hline & - Tall trees & & & & & & & & & & & & & & & \\
\hline & - $\quad$ Presence of specific tree species ${ }^{b}$ & & & & & & & & & & & & & & & \\
\hline & - $\quad$ Plenty of trees & & & & & & & & & & & & & & & \\
\hline \multirow{3}{*}{ Role in air-purification } & - Filters the air & & & & & & & & & & & & & & & \\
\hline & - "Our lungs" & & & & & & & & & & & & & & & \\
\hline & - "Mini-lungs of the neighborhood" & & & & & & & & & & & & & & & \\
\hline \multirow{5}{*}{$\begin{array}{l}\text { Place perceived as } \\
\text { valuable }\end{array}$} & - Good and valuable place & & & & & & & & & & & & & & & \\
\hline & - "The reason for moving here" & & & & & & & & & & & & & & & \\
\hline & - "Nature is beautiful and really valuable" & & & & & & & & & & & & & & & \\
\hline & $\begin{array}{l}\text { - "The rest of the neighborhood is overbuilt." } \\
\text { - "Water bodies are also important." }\end{array}$ & & & & & & & & & & & & & & & \\
\hline & $\begin{array}{l}\text {-One of the most important GS in the neighborhood } \\
\text { and the city" }\end{array}$ & & & & & & & & & & & & & & & \\
\hline \multirow{3}{*}{ Non-related to UGS } & - No traffic & & & & & & & & & & & & & & & \\
\hline & - Well planned urbanistically & & & & & & & & & & & & & & & \\
\hline & - $\quad$ Location (in the context of the city (district)) & & & & & & & & & & & & & & & \\
\hline
\end{tabular}


Focus group participants reported in total 82 locations considered as their dearest UGS attaching altogether 80 attributes to those locations. When looking at the type of tree-based UGS, majority of those locations are connected with forests (18 locations, 22 attributes attached), followed by parks (16 locations, 25 attributes), tree lines (7 locations, 8 attributes), park forest (6 locations, 12 attributes), walking paths along the streams (6 locations, 10 attributes), greenery around residential buildings (4 locations, 11 attributes), children playgrounds (4 locations, 6 attributes), greenery of sports and recreational facilities ( 3 locations, 4 attributes), private garden ( 2 locations, 1 attribute), trees (1 location, 2 attributes), window view (1 location, 4 attributes), cemeteries (1 location, 3 attributes), green system (1 location, 2 attributes), greenway (1 location, 11 attributes) and other green space (11 locations, 15 attributes). By 'other' we considered for instance greenery of educational objects or greenery around public buildings such as libraries.

When looking at the single attribute, the most frequent were positive memories and the perception of place being well maintained, both being attached to six types of UGSs (Table 3). These are followed by being a nice place for walking ( 5 types of UGS); as well as nearness/proximity, presence of shade, presence of facilities and presence of walking paths, each associated with four types of UGSs. When looking into how many times their attributes were associated with different types of tree-based UGSs, the most prominent categories were presence of facilities (associated with 9 types of UGSs), existence of emotional ties (7), possibility of experiences (7), recreational use (7), access (7), presence of trees (6), naturalness (6) and maintenance (6).

In the end when asked to report their dearest UGS, some focus group participants provided general answers not related to specific place, such as "All green space", "My favorites are UGS in my neighborhood" and "I cannot name specific UGS as being my dearest UGS" (negative meaning). However, these quotations were related to only three people out of 94 participants.

\subsection{Aesthetically Appealing Tree-Based UGS}

When asked to name tree-based UGS they consider most beautiful (aesthetically appealing) the respondents provided 83 locations attaching altogether 53 attributes (Table 4). The attributes were grouped into the following groups: accessibility, maintenance, experiences, presence of other people, presence of water bodies, emotional ties, recreational use, spiritual and restorative, facilities, naturalness, shade, openness, presence of historical and architectural objects, trees and place perceived as valuable. Majority of those locations are related to tree lines (16 locations, 6 attributes attached), forests (14 locations, 15 attributes), parks (14 locations, 27 attributes) and trees (13 locations, 7 attributes). Less frequently focus group participants mentioned private gardens (4 locations, 3 attributes), park-forests (4 locations, 7 attributes), greenery around residential buildings (3 locations, 2 attributes) and walking paths along the streams (3 locations, 9 attributes). Only one location was mentioned for each of the following types of UGSs: cemeteries (2 attributes attached), greenery of sports and recreational facilities (4 attributes), children playgrounds ( 2 attributes), window views (1 attribute) and greenways ( 8 attributes). Seven locations were grouped under other UGS (for instance green space in the vicinity of the public buildings or greenery in the vicinity of urban gardens that do not fall into any other category). Respondents mentioned five attributes related to these types of UGSs. 
Table 4. Categories and attributes with regard to aesthetically appealing tree-based urban green space (UGS). Green indicates the assignation of an attribute to particular type of UGS (F-forest, P—park, WP-walking paths along the streams, TL—tree lines, PF-park forest, GB-greenery around residential buildings, $\mathrm{CP}$-children playgrounds, SR — greenery of sports and recreational facilities, T—-trees, PG—private garden, WV—window view, C—cemeteries, GS - green system, GW-greenway, $\mathrm{O}$-other). Quotations refer to verbatim statements of the participants.

\begin{tabular}{|c|c|c|c|c|c|c|c|c|c|c|c|c|c|c|c|c|}
\hline \multirow{2}{*}{ Category } & \multirow{2}{*}{ Attributes } & \multicolumn{15}{|c|}{ Type of Tree-Based Urban Green Space } \\
\hline & & $\mathbf{F}$ & P & WP & TL & PF & GB & CP & SR & $T$ & PG & WV & C & GS & GW & $\mathbf{O}$ \\
\hline \multirow{2}{*}{ Accessibility } & - "There is nothing else" a & & & & & & & & & & & & & & & \\
\hline & - Easily accessible & & & & & & & & & & & & & & & \\
\hline Maintenance & - Well maintained & & & & & & & & & & & & & & & \\
\hline \multirow{5}{*}{ Experiences } & $\begin{array}{l}\text { - Greenness } \\
\text { - Colors } \mathrm{b} \\
\text { - Color dynamics through the year } \\
\text { - Beautiful views } \\
\text { - Pleasant scents (lime, jasmine) } \\
\text { - Sounds (frogs, water) }\end{array}$ & & & & & & & & & & & & & & & \\
\hline & $\begin{array}{l}\text { - Surprising elements } \\
\text { - Contrasts (broadleaves vs. conifers) }\end{array}$ & & & & & & & & & & & & & & & \\
\hline & $\begin{array}{l}\text { - Crown diversity } \\
\text { - Presence of animals (ducks and squirrels) }\end{array}$ & & & & & & & & & & & & & & & \\
\hline & $\begin{array}{l}\text {-Wilderness } \\
\text { - Sense of forest }\end{array}$ & & & & & & & & & & & & & & & \\
\hline & $\begin{array}{l}\text { - Combination of water and greenery (in general and } \\
\text { reflections of trees) } \\
\text { - A A tunnel made of trees" }\end{array}$ & & & & & & & & & & & & & & & \\
\hline $\begin{array}{l}\text { Presence of other } \\
\text { people }\end{array}$ & - Less or no people & & & & & & & & & & & & & & & \\
\hline \multirow{2}{*}{$\begin{array}{l}\text { Presence of water } \\
\text { bodies }\end{array}$} & $\begin{array}{l}\text { - Lake } \\
\text { - River }\end{array}$ & & & & & & & & & & & & & & & \\
\hline & $\begin{array}{l}- \text { KIver } \\
- \text { Stream } \\
\text {-Spring }\end{array}$ & & & & & & & & & & & & & & & \\
\hline Emotional ties & -Positive memories & & & & & & & & & & & & & & & \\
\hline Recreational use & $\begin{array}{l}\text { - Nice place for walking } \\
\text { - "I often go there" }\end{array}$ & & & & & & & & & & & & & & & \\
\hline \multirow{3}{*}{$\begin{array}{l}\text { Spiritual and } \\
\text { Restorative }\end{array}$} & $\begin{array}{l}\text {-Relaxing/feeling calm } \\
\text { - Magical place }\end{array}$ & & & & & & & & & & & & & & & \\
\hline & $\begin{array}{l}\text {-Magical place } \\
\text { - "I feel as I a in paradise" }\end{array}$ & & & & & & & & & & & & & & & \\
\hline & $\begin{array}{l}\text { - "So beautiful that I can just sit there and observe" } \\
\text { - Feeling protected }\end{array}$ & & & & & & & & & & & & & & & \\
\hline \multirow{2}{*}{ Facilities } & $\begin{array}{l}\text { - Presence of walking paths } \\
\text { - Human-induced design of walking paths } \\
\text { - Presence of children playgrounds }\end{array}$ & & & & & & & & & & & & & & & \\
\hline & $\begin{array}{l}\text {-Presence of children playgrounds } \\
\text { - Ice skating }\end{array}$ & & & & & & & & & & & & & & & \\
\hline \multirow[t]{3}{*}{ Naturalness } & $\begin{array}{l}\text {-Presence of tacilities (for mountaineers) } \\
\text { - Untouched forest } \\
\text { - Preserved nature }\end{array}$ & & & & & & & & & & & & & & & \\
\hline & - Presence of animals (birds of prey) & & & & & & & & & & & & & & & \\
\hline & - Presence of shade (from trees) & & & & & & & & & & & & & & & \\
\hline
\end{tabular}


Table 4. Cont.

\begin{tabular}{|c|c|c|c|c|c|c|c|c|c|c|c|c|c|c|c|c|}
\hline \multirow{2}{*}{ Category } & \multirow{2}{*}{ Attributes } & \multicolumn{15}{|c|}{ Type of Tree-Based Urban Green Space } \\
\hline & & $\mathbf{F}$ & $\mathbf{P}$ & WP & TL & PF & GB & $\mathrm{CP}$ & SR & $T$ & PG & wV & $\mathrm{C}$ & GS & GW & $\mathrm{O}$ \\
\hline \multirow{2}{*}{ Openness } & - Open view & & & & & & & & & & & & & & & \\
\hline & - Open space & & & & & & & & & & & & & & & \\
\hline \multirow{3}{*}{$\begin{array}{l}\text { Presence of historical } \\
\text { and architectural objects }\end{array}$} & - (Wooden) bridges & & & & & & & & & & & & & & & \\
\hline & - Old chapel & & & & & & & & & & & & & & & \\
\hline & - Archaeological site & & & & & & & & & & & & & & & \\
\hline \multirow{5}{*}{ Trees } & - Presence of trees & & & & & & & & & & & & & & & \\
\hline & - Trees perceived as mighty & & & & & & & & & & & & & & & \\
\hline & - Old trees & & & & & & & & & & & & & & & \\
\hline & - Large crowns & & & & & & & & & & & & & & & \\
\hline & $\begin{array}{l}\text { - Large flowers } \\
\text { c. Presence of specific tree species } c\end{array}$ & & & & & & & & & & & & & & & \\
\hline \multirow{3}{*}{$\begin{array}{l}\text { Place perceived as } \\
\text { valuable }\end{array}$} & - "The rest of the neighborhood is overbuilt" & & & & & & & & & & & & & & & \\
\hline & - "Center of the world for our neighborhood" & & & & & & & & & & & & & & & \\
\hline & - Place perceived as having a potential & & & & & & & & & & & & & & & \\
\hline
\end{tabular}

a Being perceived as the only UGS in the vicinity or the neighborhood; ${ }^{\mathrm{b}}$ Leaves other than green, flowers; ${ }^{\mathrm{c}}$ Pine trees (Pinus), plane trees (Platanus), Japanese cherry (Prunus serrulata Lindl.), nettle tree (Celtis), weeping willow (Salix babylonica L.), magnolia trees (Magnolia), horse chestnut trees (Aesculus hippocastanum L.), Sequoia trees (Sequoia sempervirens (D. Don) Endl.)), cedar (Cedrus), solitary Lombardy poplar trees (Populus nigra 'Italica'). 
Most pronounced single attributes were presence of specific tree species (related to 7 types of UGSs), presence of trees in general (5), beautiful views (5) and presence of colorful leaves (other than green) (Table 4). Possibility of experiences was the richest category, based on how many times their attributes were associated with various types of UGSs (14 attributes appeared 30 times across 10 types of UGSs). In second place was the trees category (6 attributes appeared 18 times across 11 types of UGSs). These categories were followed by spiritual and restorative category (relevant for 5 types of UGSs) and presence of water bodies (4 types of UGSs). Other categories were present to a lesser extent when looking at how many times their attributes appeared across various types of UGSs.

\subsection{Recreational Use of Tree-Based UGS}

Focus group participants mentioned 11 types of recreational activities and 12 types of UGSs where they practice those activities (Table 5). Types of UGSs they reported depended on the activity. For instance, hunting and mushroom picking were only possible in forests, while walking as the most popular activity was exercised in 11 types of tree-based UGSs. Results showed that forests and greenery of sports and recreational facilities in Zagreb provide more opportunities for various recreational activities than other types of UGSs. Observing nature was mapped only in the context of window view greenery. We are aware that it is also part of walkers' or other types of recreational users' activities, even though they did not specifically reported it. Focus group participants reported altogether 52 locations for walking of which forests and park were the most frequent (10 locations each); followed by tree-lines (8); walking paths along streams (5); park forest and children playground (4 locations each); greenery of sports and recreational facilities and greenery around residential buildings (3 locations each); private garden and other UGS (2 locations each); and greenway (1). Jogging was reported in relation with five types, while bicycling was related to four types of tree-based UGSs. In two cases participants did not mention specific activity they do in UGS of their city district, and stated that they do not use UGSs in their city districts for recreational purposes.

Table 5. Recreational use of tree-based urban green spaces (UGSs). Green indicates the assignation of recreational activity to a particular type of UGS (F-forest, $\mathrm{P}$-park, WP-walking paths along the streams, TL-tree lines, PF-park forest, GB-greenery around residential buildings, $\mathrm{CP}$-children playgrounds, $\mathrm{SR}$ - greenery of sports and recreational facilities, $\mathrm{PG}$ - private garden, WV-window view, GS—green system, GW—greenway, $\mathrm{O}$ —other).

\begin{tabular}{|c|c|c|c|c|c|c|c|c|c|c|c|c|}
\hline \multirow{2}{*}{ Category } & \multicolumn{12}{|c|}{ Types of Tree-Based Urban Green Spaces } \\
\hline & F & $\mathbf{P}$ & WP & TL & PF & GB & $\mathrm{CP}$ & SR & PG & WV & GW & O \\
\hline \multicolumn{13}{|l|}{ Boules } \\
\hline \multicolumn{13}{|l|}{ Bicycling } \\
\hline \multicolumn{13}{|l|}{ Grilling } \\
\hline \multicolumn{13}{|l|}{ Hunting } \\
\hline \multicolumn{13}{|l|}{ Jogging } \\
\hline \multicolumn{13}{|l|}{ Mountain climbing } \\
\hline \multicolumn{13}{|l|}{ Mushroom picking } \\
\hline \multicolumn{13}{|l|}{ Observing nature } \\
\hline \multicolumn{13}{|l|}{ Picnicking } \\
\hline \multicolumn{13}{|l|}{ Skating } \\
\hline Walking & & & & & & & & & & & & \\
\hline
\end{tabular}

\subsection{Educational Services of Tree-Based UGS}

Question about existing of potential tree-based UGSs that are or could be used for educational purposes about green space or nature in general elicited modest discussion among focus group participants. There were three groups of answers. First group of answers were those related mainly 
to specific locations that could potentially be used for education, with only two locations mentioned that had already been used for such purposes. The second and third groups of answers were those of general character. The former was about how children learn (intuitively, by touching, should be left alone to explore) and some were of the opinion that any green space can potentially be an educational ground for children. In the end a few respondents were not aware of such locations, never thought about it or generally did not perceive any green space as being suitable for the purpose at the moment.

When looking into specific locations they mentioned most of these are related to forests (7 location) and parks (5 of which two are historical parks), and to a lesser extent to greenery of educational facilities such as schools and kindergartens (3), park-forests (2), greenery around residential objects (1), greenery of sports and recreational facilities (1), green system (1) and other green space (2). Focus groups participants were mainly unable to elaborate further about what attributes green spaces should have to be suitable for educational purposes. However, there were some hints or potential attributes that could be interpreted from the discussion. These were closeness to schools and kindergartens, existence of facilities (e.g., hunting lodge), presence of water bodies (streams, waterfalls) or geological formations (caves or significant rocks), historical parks and having name tags on trees. The commonality that runs through all the focus groups was that nature education was considered only for children (either those in kindergartens or in elementary schools).

\subsection{Cultural Identity Services of Tree-Based UGSs}

Focus group participants provided altogether 34 locations perceived as being part of the cultural identity of their neighborhood or even the city district. These were related to nine types of tree-based UGSs, mainly to parks (12 locations, some of which were historical parks, 6 attributes), somewhat lesser to forests (6 locations, 4 attributes), park-forests (4 locations, 4 attributes), greenery of sports and recreational facilities (4 locations, 2 attributes), and rarely to tree lines (2 locations, 2 attributes), walking paths along streams ( 2 locations, 1 attribute), greenery around residential buildings (1 location, 2 attributes), greenways (1 location, 2 attributes) and other green space (2 locations, 1 attribute).

Based on the interpretation of data from the transcripts we were able to identify several attributes related to UGS perceived as bearing a cultural identity (Table 6).

Table 6. Cultural identity of tree-based urban green space (UGS). Green indicates the assignation of attributes to particular type of UGS (F-forest, $\mathrm{P}$ - park, WP-walking paths along the streams, TL — tree lines, $\mathrm{PF}$ - park forest, GB — greenery around residential buildings, SR — greenery of sports and recreational facilities, GW-greenway, $\mathrm{O}$ - other).

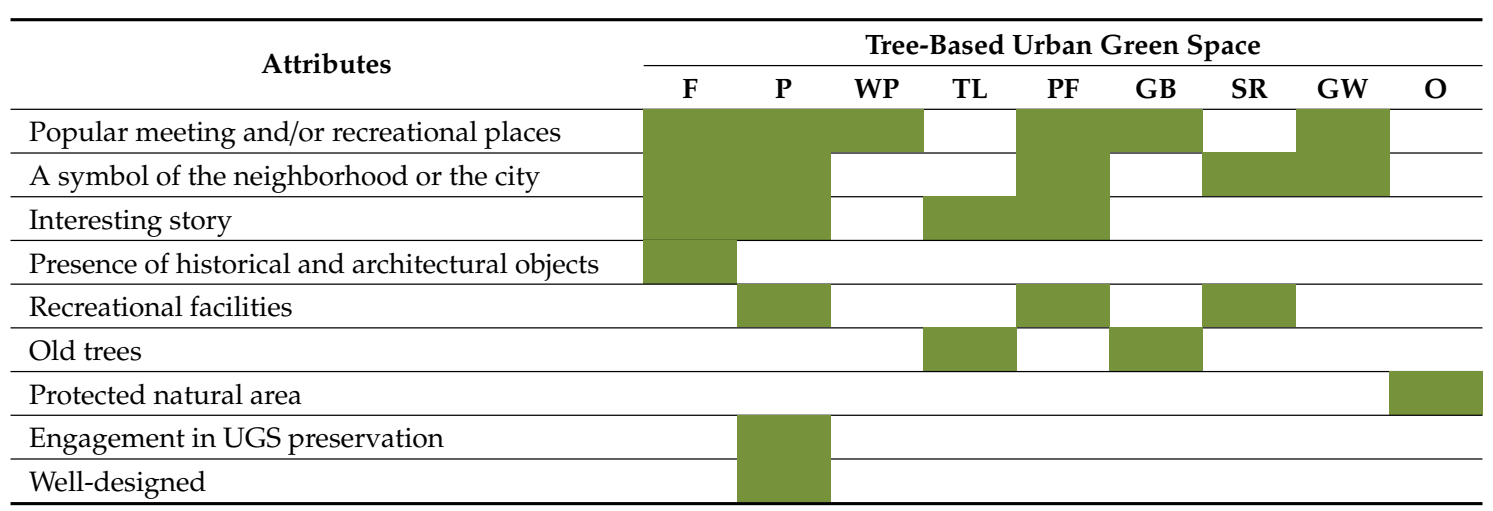

Mostly these were UGSs that are popular meeting and/or recreational places (associated with 6 types of UGSs), visited by many people from the neighborhood or entire city district or from other city districts, or UGS being well known even for people outside the city district, those perceived as highly recognized as a symbol of the neighborhood or the city (attribute attached to 5 types of UGSs). Another important attribute (associated with 4 types of UGSs) was existence of an interesting story-for instance Park of the newlyweds that was established with donations of newlyweds who 
had an opportunity to choose the tree species, donations were entered into a register and they received the certificate for the donation [46]. Some other was related to folk stories and legends. For instance, location Kameni svati (in translation Stone wedding) refers to a rock formation in the forest on the mountain Medvednica. The folk story based in Slavic mythology says that curse was inflicted on the wedding procession and they turned into stone [47]. In one case the particular green space with its yew trees (Taxus baccata L.) was on the cover photo of the popular New Wave rock band's album from the 1980s [48]. Lastly, a neighborhood Retkovec in one of the city districts has an interesting toponymy-all streets are named after tree species, hence the Maple Alley, Birch Street, Oak Street, etc. In the 1960s, those streets were lined with tree lines of the same species these streets were named after. Trees were planted voluntarily by citizens as part of the national tree planting campaign at the time "Every person each year a single tree" [46]. Other attributes included presence of historical and architectural objects, however, attached only to forests, for instance dilapidated fortress Susedgrad (also appears in a folk legend) or old water mills; having recreational facilities (attached to parks, park forests and greenery of sports and recreational facilities); existence of old trees (attached to tree lines and greenery around residential buildings); as well as existence of protected natural area (in our case ornithological reserve), engagement in UGS preservation and UGS being perceived as well-designed, all attached to single types of UGSs.

\subsection{Summary of Perceived CES Provided by Various Types of Tree-Based UGSs}

Focus group participants perceived various types of UGSs provide CES, even though some where most pronounced by others (Table 7). Forests and parks, as well as park-forests, greenery around residential buildings and greenery of sport and recreational facilities were consistently recognized by participants as providing various CES to urban residents. However, place attachment was perceived in relation to all 15 identified types of UGSs, 14 types of UGSs were recognized as aesthetically appealing, recreational services were connected with 11 types, cultural identity to nine and educational services to eight types of UGSs. Individual trees, cemeteries and green system were in general less recognized as sources of recreational services. It is no surprise that participants did not associate recreational service to individual trees. Regarding the green system, it is located in the busy city center which may be the reason why it was not recognized as source of recreational services.

Table 7. Perceived cultural ecosystem services (CES) by various types of tree-based urban green spaces (UGSs). Green indicates the assignation of CES to particular type of UGS. (F-forest, P-park, $\mathrm{WP}$ - walking paths along the streams, TL—-tree lines, PF—park forest, GB — greenery around residential buildings, $\mathrm{CP}$ —children playgrounds, $\mathrm{SR}$ — greenery of sports and recreational facilities, $\mathrm{PG}$ - private garden, WV—window view, GS-green system, GW—greenway, O-other).

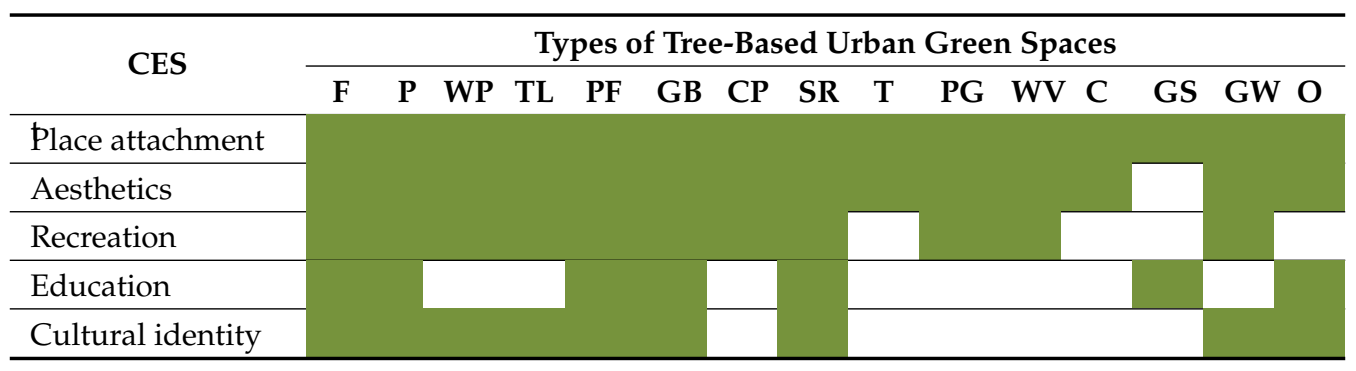

\section{Discussion}

The results showed numerous attributes people attached to various types of tree-based UGSs (Tables 3 and 4). Number of attributes differed between different categories of CES-expectedly the most attributes being attached with their dearest UGS. Somewhat less attributes were connected with UGS considered as aesthetically appealing (beautiful). The least number of attributes was related to educational and cultural identity services of UGSs, probably because participants in general discussed 
less about these services. Another possible reason might be that these services had been less important for them or more difficult to grasp in comparison to place attachment, aesthetics and recreational use of UGS.

When looking into results related to their dearest place, unsurprisingly most important attributes for several types of UGSs were having previous positive memories (e.g., childhood spent) and the perception of place being well maintained. Indeed studies show that humans often have emotional responses to their natural environment that may be both positive and negative [11,19,49]. Additionally, when looking at the most important categories (groups of attributes) for various types of UGS, besides maintenance and having emotional ties, others were mostly related to the utilitarian character of UGS, or in other words, possibility of UGS to be used for recreational and other experiences (having access, facilities, place suites recreational purposes, possibility of various experiences while being there). This is in line with many other studies stating that access, facilities and proper maintenance are among the most favorable characteristics of UGSs [34,50,51]. Nearness of public UGS was considered important for the accessibility by our respondents. Having accessible UGS within the $300 \mathrm{~m}$ from home has become an urban planning mantra since studies show that it increases the use of UGS and human wellbeing [52,53]. However there is also evidence that people may not use their nearest UGS for various reasons [54]. Possibility of various experiences and sense of mystery also prove important for human landscape preferences [55]. Last, but not least, naturalness was pronounced in relation to forests, parks and park-forests, but also greenery of sports and recreational facilities, greenway and other. The presence of trees, especially those old or tall or even specific species were almost equally pronounced albeit connected with somewhat different types of UGSs (only having parks in common) (Table 3). Trees have symbolic meanings to humans [56]. Studies on human preferences for tree characteristics show that tall, wide and deciduous trees are most preferred [21]. Our participants explained naturalness as presence of "true" forest, well preserved, with perceived biodiversity. Forests and parks were the most pronounced as dearest UGS and participants attached the most attributes to these particular types of UGSs (Table 3). They provided somewhat less attributes for park-forests, greenery around residential buildings, walking paths along the streams, greenways and other UGS. Interestingly, only one greenway collected 11 attributes based on the perception of participants. Private gardens were mentioned only twice but unfortunately in the context of lack of access to public UGS, because "There is nothing else" (Table 3). Some other types of UGSs such as green systems or cemeteries were not so much in focus of our respondents. For cemeteries it might be also cultural issue, in a sense that people might not consider cemeteries as pleasant places, but we cannot be sure. A participant mentioned that people avoid cemeteries of mental institutions in his city district because in his opinion they might have negative connotations.

Similar to dearest UGS, participants again mostly reported parks and forests as locations they perceived aesthetically appealing, and as well attached more attributes to those than other types of UGS (Table 4). Tree lines were also among most pronounced types of UGSs, even though with much less attributes associated in comparison to parks and forests. Presence of specific tree species was the most important single attribute, followed with presence of trees in general and specific tree attributes such as old and mighty trees (participants referred to plane trees), or trees with large crowns and flowers (participants referred to Japanese cherry, horse chestnut trees and magnolia trees). Additionally, presence of water combined with greenery was preferred. Studies show that presence of trees and water in landscape increases aesthetic preferences [57]. Plane trees and deciduous trees in general are among those most preferred [21]. Additionally, under the preferred experiences our participants reported contrasting and surprising elements, color dynamics (including seasonal changes), greenness and presence of colors other than green. This is in line with studies showing that color in the landscape impacts visual preferences [58-61]. For instance, green and red colors of trees are preferred more than purple and orangish-brown trees [59]. Similarly, presence of colorful flowers increases aesthetic appeal of UGS [61]. When comparing categories related to dearest and aesthetically appealing UGS, we identified less categories for the latter services, with categories of beauty, role of 
UGS in air-purification and group of attributes non-related to UGS omitted. Aesthetic appreciation was less related to recreational use than dearest UGS (Tables 3 and 4). However, we conclude similar to Riechers and colleagues [24] that recreation was important for our participants, and somewhat an underlying goal of their interaction with UGS. In general trees with their various features, regardless of the type of UGS, proved important for both place attachment and aesthetics.

One of the important attributes for educational UGS was proximity to educational institutions (kindergartens and schools). This is also supported in one of the most recent studies including preferences of teachers for preferred characteristics of UGS for educational purposes [62]. Place being popular among residents for socializing and recreational purposes, recognized beyond the boards of the city districts or even the city, as well as having a good story, were most important attributes of UGS providing cultural identity services.

We identified an overlap between groups of CES. For instance, the same UGSs were sometimes considered both dearest and aesthetically appealing. Furthermore, UGSs used and perceived as those providing recreational services were sometimes pronounced as dearest and beautiful as well. The result is in line with results of similar studies [24,63]. Additionally, two regulating services, air-purification and cooling effect (or in our case category 'shade') were attached to dearest UGS and aesthetic services, which further supports overlap and bundling of ecosystem services not only among CES, but also between CES and other groups of ecosystem services.

\section{Conclusions}

The city-wide exploratory study provided insights into how people perceive and use tree-based UGS in terms of what CES they perceive and use, as well as what services they connect to different types of tree-based UGSs. Participants perceived all investigated CES, however, place attachment, aesthetics and recreational services were more pronounced than other. We were able to identify a wide range of attributes as well as many overlapping categories attached to both place attachment and aesthetics. Forests and parks were consistently those most pronounced in relation to investigated CES. However, other types of UGSs were proved important as well even though with various numbers of attributes and categories attached. The study supports the need for carefully planned quality tree-based UGS including variety of green space types.

The value of our study is manifold. CES studies of UGSs rarely address these services at the city scale (c.f. $[24,64]$ for exceptions) and our study covered the whole city based on the data collection covering all city districts. Furthermore, CES studies, as identified in the introduction, often do not specify type of UGS or include single UGS or single type of UGS (e.g., [10,23]). In our study we covered all tree-based types of UGSs, hence expanding from the usual types of UGS covered in CES studies, such as parks and forests. Our study covered also less explored CES such as cultural identity and educational services of tree-based UGSs. In the end, we used qualitative bottom-up approach to identify CES of UGSs as perceived by people. In the study area this study is the first exploring perception of CES provided by different types of UGSs. Focus group discussion with residents are in a way application of a participatory approach to UGS planning and management, the practice that is still missing in the study area where there is no attempt of city's UGS planners or managers to monitor or include people's perception [35]. As already mentioned in the introduction, qualitative CES studies of UGSs are still rare. However, focus groups provided richness of the data that would not be possible to achieve with quantitative surveys, especially since there is no previous studies in the study area covering various CES. Hence, this approach provided good foundation for the public participatory GIS that will be developed in the second phase of the project for the purpose of quantifying CES from tree-based UGS. Focus groups allowed better understanding how people perceive and talk about services and benefits provided by UGS. Results provided by the study may be relevant for urban and UGS planners and mangers, hence being in line with the need for landscape planners to focus not only on physical landscape and expert based approaches, but also on social landscape [65]. 
Author Contributions: Conceptualization, S.K.O. and D.V.; methodology, S.K.O., focus group moderation, S.K.O., A.M.M. and M.K.; analysis, S.K.O. and A.M.M.; writing, S.K.O., A.M.M., M.K. and D.V.; visualization, A.M.M. and M.K. All authors have read and agreed to the published version of the manuscript.

Funding: This research was funded by the Croatian Science Foundation, through project "Improving green infrastructure planning and management through participatory mapping of cultural ecosystem services" (CULTUR-ES), grant number UIP-2017-05-1986.

Acknowledgments: Authors acknowledge time and effort of focus group participants without whom this research would not be possible. We also acknowledge support of the City Office for the Local Self-Administration of the City of Zagreb, all City Districts and Municipal Boards, as well as Libraries of the City of Zagreb who provided us with space for conducting focus groups with citizens free of charge. In addition, our gratitude goes to two anonymous reviewers for their thoughtful comments.

Conflicts of Interest: The authors declare no conflict of interest. The funders had no role in the design of the study; in the collection, analyses, or interpretation of data; in the writing of the manuscript, or in the decision to publish the results.

\section{Appendix A}

\section{Focus group protocol}

(Introduction has been left out)

1. What are your dearest urban green spaces in your city district and why?

2. What urban green spaces in your city district you visit the most and why?

3. Are there any urban green spaces in your city district that you find beautiful (aesthetically pleasing)? What are they and why?

4. Are there any urban green spaces in your city district that you find important for your district's or Zagreb's cultural identity? Which are those and why?

5. Are there any urban green spaces in your city district that you find important for nature education of citizens? Which are those and why?

6. Are there any urban green spaces where you would never go? Which are those and why?

7. Is there any urban green space in your city district that in your opinion should be protected at any cost, and why? Is there any urban green space in your city district that is the least important in your opinion and could easily be sacrificed, and why?

\section{Appendix B}

\section{Sociodemographic questionnaire}

1. I am male/female. (Please encircle the relevant answer)

2. I was born in (Please write the year of your birth)

3. The highest level of education you have achieved:

(a) Elementary school

(b) High school/Grammar school

(c) Vocational school

(d) Upper secondary education

(e) Bachelor's degree

(f) Master's degree

(g) Post-graduate degree (MSc, $\mathrm{PhD}$ )

(h) Other: (e.g., without elementary school, student ... )

4. I live:

(a) In a house 
(b) In an apartment building

5. I grew up:
(a) In the city
(b) At the countryside

6. I have been living in Zagreb for years.

7. I have been living in this city district for years.

8. There are persons in my household. (Please write number of persons living in your household)

9. There are ___ preschool children in my household. (Please write number of preschool children)

10. I am currently:
(a) Employed
(b) Unemployed
(c) Student
(d) Retired

11. Monthly income of my household in Croatian kuna (HRK) is:

(a) Less than 7300 HRK (less than 1 average monthly net earnings in HRK for the City of Zagreb)

(b) 7300 to 14,600 HRK (between 1 and 2 average monthly net earnings in HRK for the City of Zagreb)

(c) More than 14,600 HRK (more than 2 average monthly net earnings in HRK for the City of Zagreb)

\section{References}

1. United Nations, Department of Economic and Social Affairs, P.D. World Urbanization Prospects: The 2018 Revision (ST/ESA/SER.A/420); United Nations: New York, NY, USA, 2019; Volume 12.

2. EUROSTAT. Urban Europe: Statistics on Cities, Towns and Suburbs; Marijana, K., Teodóra, B., Luliana, L., Åsa, Ö., Louise, C.-N., Catherine, C., Annika, J., Helene, S., Wolff, P., Eds.; European Commission: Luxembourg, 2016; ISBN 9789279601392.

3. Plieninger, T.; Bieling, C. (Eds.) Resilience and the Cultural Landscape: Understanding and Managing Change in Human-Shaped Environments; Cambridge University Press: Cambridge, UK, 2012; ISBN 9781139107778.

4. Millennium Ecosystem Assessment. Ecosystems and Human Well-being: Synthesis; Island Press: Washington, DC, USA, 2005.

5. Milcu, A.I.; Hanspach, J.; Abson, D.; Fischer, J. Cultural Ecosystem Services: A Literature Review and Prospects for Future Research. Ecol. Soc. 2013, 18, art44. [CrossRef]

6. Chang, J.; Qu, Z.; Xu, R.; Pan, K.; Xu, B.; Min, Y.; Ren, Y.; Yang, G.; Ge, Y. Assessing the ecosystem services provided by urban green spaces along urban center-edge gradients. Sci. Rep. 2017, 7, 1-9. [CrossRef]

7. Salbitano, F.; Borelli, S.; Conigliaro, M.; Azlin Yahya, N.; Sanesi, G.; Chen, Y.; Tovar Corzo, G. Urban forest benefits in developing and industrialised countries. In Routledge Handbook of Urban Forestry; Ferrini, F., Konijnendijk van den Bosch, C.C., Fini, A., Eds.; Routledge: London, UK; New York, NY, USA, 2017; pp. 136-151; ISBN 978-0-367-35238-7.

8. Roy, S.; Byrne, J.; Pickering, C. A systematic quantitative review of urban tree benefits, costs, and assessment methods across cities in different climatic zones. Urban For. Urban Green. 2012, 11, 351-363. [CrossRef]

9. van Vliet, K.; Hammond, C. Residents' perceptions of green infrastructure in the contemporary residential context: A study of Kingswood, Kingston-upon-Hull, England. J. Environ. Plan. Manag. 2020, 1-19. [CrossRef]

10. Buchel, S.; Frantzeskaki, N. Citizens' voice: A case study about perceived ecosystem services by urban park users in Rotterdam, the Netherlands. Ecosyst. Serv. 2015, 12, 169-177. [CrossRef] 
11. Konijnendijk, C.C. The Forest and the City: The Cultural Landscape of Urban Woodland, 1st ed.; Springer: Dordrecht, The Netherlands, 2008; ISBN 978-1-4020-8370-9.

12. European Landscape Convention; Council of Europe: Florence, Italy, 2000.

13. Steg, L.; van den Berg, A.E.; de Groot, J.I.M. Environmental Psychology: History, Scope, and Methods. In Environmental Psychology: An Introduction; Steg, L., de Groot, J.I.M., Eds.; Wiley: Hoboken, NJ, USA, 2019; pp. 1-11; ISBN 978-1-119-24108-9.

14. Tveit, M.S.; Ode Sang, Å.; Hagerhall, C.M. Scenic Beauty: Visual Landscape Assessment and Human Landscape Perception. In Environmental Psychology: An Introduction; Steg, L., de Groot, J.I.M., Eds.; Wiley: Hoboken, NJ, USA, 2019; pp. 45-54; ISBN 978-1-119-24108-9.

15. Jim, C.Y.; Chen, W.Y. Recreation-amenity use and contingent valuation of urban greenspaces in Guangzhou, China. Landsc. Urban Plan. 2006, 75, 81-96. [CrossRef]

16. Hägerhäll, C.M.; Sang, Å.O.; Englund, J.E.; Ahlner, F.; Rybka, K.; Huber, J.; Burenhult, N. Do humans really prefer semi-open natural landscapes? A cross-cultural reappraisal. Front. Psychol. 2018, 9, 1-14. [CrossRef]

17. Peters, K.; Elands, B.; Buijs, A. Social interactions in urban parks: Stimulating social cohesion? Urban For. Urban Green. 2010, 9, 93-100. [CrossRef]

18. Hoyle, H.; Jorgensen, A.; Hitchmough, J.D. What determines how we see nature? Perceptions of naturalness in designed urban green spaces. People Nat. 2019, 167-180. [CrossRef]

19. Townsend, J.B.; Barton, S. The impact of ancient tree form on modern landscape preferences. Urban For. Urban Green. 2018, 34, 205-216. [CrossRef]

20. Zhao, J.; Xu, W.; Li, R. Visual preference of trees: The effects of tree attributes and seasons. Urban For. Urban Green. 2017, 25, 19-25. [CrossRef]

21. Hofmann, M.; Gerstenberg, T.; Gillner, S. Predicting tree preferences from visible tree characteristics. Eur. J. For. Res. 2017, 136, 421-432. [CrossRef]

22. Gerstenberg, T.; Hofmann, M. Perception and preference of trees: A psychological contribution to tree species selection in urban areas. Urban For. Urban Green. 2016, 15, 103-111. [CrossRef]

23. Dickinson, D.C.; Hobbs, R.J. Cultural ecosystem services: Characteristics, challenges and lessons for urban green space research. Ecosyst. Serv. 2017, 25, 179-194. [CrossRef]

24. Riechers, M.; Barkmann, J.; Tscharntke, T. Perceptions of cultural ecosystem services from urban green. Ecosyst. Serv. 2016, 17, 33-39. [CrossRef]

25. Zwierzchowska, I.; Hof, A.; Iojă, I.C.; Mueller, C.; Poniży, L.; Breuste, J.; Mizgajski, A. Multi-scale assessment of cultural ecosystem services of parks in Central European cities. Urban For. Urban Green. 2018, 30, 84-97. [CrossRef]

26. Romolini, M.; Ryan, R.L.; Simso, E.R.; Strauss, E.G. Visitors' attachment to urban parks in Los Angeles, CA. Urban For. Urban Green. 2019, 41, 118-126. [CrossRef]

27. Bertram, C.; Rehdanz, K. Preferences for cultural urban ecosystem services: Comparing attitudes, perception, and use. Ecosyst. Serv. 2015, 12, 187-199. [CrossRef]

28. Ko, H.; Son, Y. Perceptions of cultural ecosystem services in urban green spaces: A case study in Gwacheon, Republic of Korea. Ecol. Indic. 2018, 91, 299-306. [CrossRef]

29. O’Brien, L.; De Vreese, R.; Kern, M.; Sievänen, T.; Stojanova, B.; Atmiş, E. Cultural ecosystem benefits of urban and peri-urban green infrastructure across different European countries. Urban For. Urban Green. 2017, 24, 236-248. [CrossRef]

30. Rupprecht, C.D.D.; Byrne, J.A.; Ueda, H.; Lo, A.Y. 'It's real, not fake like a park': Residents' perception and use of informal urban green-space in Brisbane, Australia and Sapporo, Japan. Landsc. Urban Plan. 2015, 143, 205-218. [CrossRef]

31. Quinton, J.M.; Duinker, P.N. Beyond burial: Researching and managing cemeteries as urban green spaces, with examples from Canada. Environ. Rev. 2018, 27, 252-262. [CrossRef]

32. Sikorska, D.; Łaszkiewicz, E.; Krauze, K.; Sikorski, P. The role of informal green spaces in reducing inequalities in urban green space availability to children and seniors. Environ. Sci. Policy 2020, 108, 144-154. [CrossRef]

33. Krajter Ostoić, S.K.; Vuletić, D.; Planinšek, Š.; Vilhar, U.; Japelj, A. Three Decades of Urban Forest and Green Space Research and Practice in Croatia and Slovenia. Forests 2020, 11, 136. [CrossRef]

34. Krajter Ostoić, S.; Konijnendijk van den Bosch, C.C.; Vuletić, D.; Stevanov, M.; Živojinović, I.; Mutabdžija-Bećirović, S.; Lazarević, J.; Stojanova, B.; Blagojević, D.; Stojanovska, M.; et al. Citizens' perception 
of and satisfaction with urban forests and green space: Results from selected Southeast European cities. Urban For. Urban Green. 2017, 23, 93-103. [CrossRef]

35. Krajter Ostoić, S. Analysis of current urban forest governance in the city of Zagreb. Ph.D. Thesis, University of Zagreb, Zagreb, Croatia, 2013.

36. City of Zagreb. Statistical Yearbook of the City of Zagreb 2019; City of Zagreb: Zagreb, Croatia, 2019.

37. Maruševski, O.; Jurković, S. Maksimir; Školska knjiga: Zagreb, Croatia, 1992; ISBN 86-03-00523-0.

38. Knežević, S. Zagrebačka zelena potkova (Zagreb's Green Horseshoe); Školska knjiga d.d. Zagreb; FS d.o.o.: Zagreb, Croatia, 1996; ISBN 953-0-60524-2.

39. Matić, S.; Anić, I. (Eds.) Park-šume grada Zagreba; Academy of Forestry Sciences: Zagreb, Croatia, 2010; ISBN 9789539857149.

40. Vujasinović, B. Uloga rijeke Save u povijesnom razvoju grada Zagreba (Role of the river Sava in historical development and growth of the city of Zagreb). Ekon. i Ekohist. 2007, 3, 121-155.

41. Stewart, D.W.; Shamdasani, P.N.; Rook, D.W. Focus Groups: Theory and Practice, 2nd ed.; SAGE Publications Inc.: Thousand Oaks, CA, USA, 2007; ISBN 978-0-7619-2583-5.

42. Skoko, B.; Benković, V. Znanstvena metoda fokus grupa - mogućnosti i načini primjene. Polit. Misao 2009, XLVI, 217-236.

43. Krueger, R. Analyzing \& Reporting Focus Group Results; SAGE Publications, Inc.: Thousand Oaks, CA, USA, 1998; ISBN 9780761908166.

44. Harry, B.; Sturges, K.M.; Klingner, J.K. Mapping the Process: An Exemplar of Process and Challenge in Grounded Theory Analysis. Educ. Res. 2005, 34, 3-13. [CrossRef]

45. Saldaña, J. The Coding Manual for Qualitative Researchers; SAGE Publications Ltd.: London, UK, 2009; ISBN 978-1-84787-549-5.

46. Jelić, S. Svaki građanin svake godine jedno stablo; Vincenski, P., Ed.; Second; Fond za zelenilo "Stablo mladosti", Zagreb: Zagreb, Croatia, 1972.

47. Đermek, A. Slavenski mitski trokut i legenda o Kamenim svatima. Stud. Myth. Slavica 2009, XII, 223-247. [CrossRef]

48. Bosno, K. Štulićeva tisa: Priča o kultnoj fotografiji nastaloj sasvim slučajno. Available online: https://web.archive.org/save/https://zadovoljna.dnevnik.hr/clanak/stuliceva-tisa-prica-o-kultnojfotografiji-s-omota-albuma-filigranski-plocnici---516816.html (accessed on 28 June 2020).

49. Skår, M. Forest dear and forest fear: Dwellers' relationships to their neighbourhood forest. Landsc. Urban Plan. 2010, 98, 110-116. [CrossRef]

50. Mertens, L.; Van Cauwenberg, J.; Veitch, J.; Deforche, B.; Van Dyck, D. Differences in park characteristic preferences for visitation and physical activity among adolescents: A latent class analysis. PLoS ONE 2019, 14, e212920. [CrossRef] [PubMed]

51. Wan, C.; Shen, G.Q.; Choi, S. Effects of physical and psychological factors on users' attitudes, use patterns, and perceived benefits toward urban parks. Urban For. Urban Green. 2020, 51, 126691. [CrossRef]

52. Özgüner, H. Cultural Differences in Attitudes towards Urban Parks and Green Spaces. Landsc. Res. 2011, 36, 599-620. [CrossRef]

53. Grilli, G.; Mohan, G.; Curtis, J. Public park attributes, park visits, and associated health status. Landsc. Urban Plan. 2020, 199, 103814. [CrossRef]

54. Schipperijn, J.; Stigsdotter, U.K.; Randrup, T.B.; Troelsen, J. Influences on the use of urban green space - A case study in Odense, Denmark. Urban For. Urban Green. 2010, 9, 25-32. [CrossRef]

55. Kaplan, R.; Kaplan, S.; Brown, T. Environmental Preference. Environ. Behav. 1989, 21, 509-530. [CrossRef]

56. Dwyer, J.F.; Schroeder, H.W.; Gobster, P.H. The significance of urban trees and forests: Toward a deeper understanding of values. J. Arboric. 1991, 17, 276-284.

57. Wang, R.; Zhao, J.; Meitner, M.J.; Hu, Y.; Xu, X. Characteristics of urban green spaces in relation to aesthetic preference and stress recovery. Urban For. Urban Green. 2019, 41, 6-13. [CrossRef]

58. Ma, B.; Hauer, R.J.; Xu, C. Effects of design proportion and distribution of color in urban and suburban green space planning to visual aesthetics quality. Forests 2020, 11, 278. [CrossRef]

59. Kaufman, A.J.; Lohr, V.I. Does plant color affect emotional and physiological responses to landscapes? Acta Hortic. 2004, 639, 229-233. [CrossRef]

60. Polat, A.T.; Akay, A. Relationships between the visual preferences of urban recreation area users and various landscape design elements. Urban For. Urban Green. 2015, 14, 573-582. [CrossRef] 
61. Campagnaro, T.; Vecchiato, D.; Arnberger, A.; Celegato, R.; Da Re, R.; Rizzetto, R.; Semenzato, P.; Sitzia, T.; Tempesta, T.; Cattaneo, D. General, stress relief and perceived safety preferences for green spaces in the historic city of Padua (Italy). Urban For. Urban Green. 2020, 52, 126695. [CrossRef]

62. Nastran, M. Visiting the Forest with Kindergarten Children: Forest Suitability. Forests 2020, 11, 696. [CrossRef]

63. Bieling, C. Cultural ecosystem services as revealed through short stories from residents of the Swabian Alb (Germany). Ecosyst. Serv. 2014, 8, 207-215. [CrossRef]

64. Rall, E.; Bieling, C.; Zytynska, S.; Haase, D. Exploring city-wide patterns of cultural ecosystem service perceptions and use. Ecol. Indic. 2017, 77, 80-95. [CrossRef]

65. Ryan, R.L. The social landscape of planning: Integrating social and perceptual research with spatial planning information. Landsc. Urban Plan. 2011, 100, 361-363. [CrossRef]

(C) 2020 by the authors. Licensee MDPI, Basel, Switzerland. This article is an open access article distributed under the terms and conditions of the Creative Commons Attribution (CC BY) license (http://creativecommons.org/licenses/by/4.0/). 